Nuclear Technology - Chemistry and Chemical Engineering

AEC Research and Development Report

\title{
RECOVERY OF NEPTUNIUM FROM STORED PUREX WASTE
}

by

M. D. Snyder

Separations Chemistry Division

September 1962

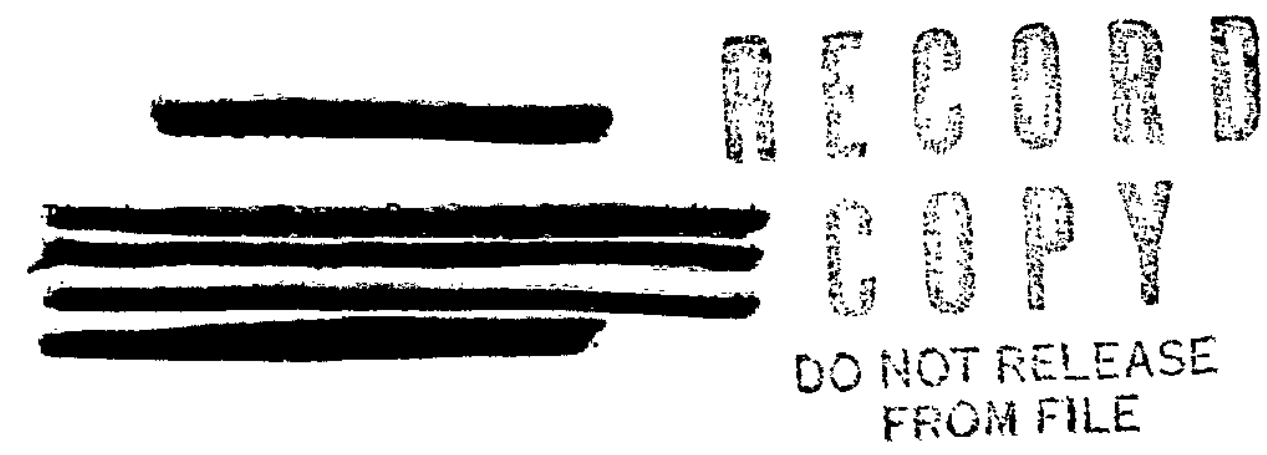

E. I. du Pont de Nemours \& Co.

Savannah River Laboratory

Aiken, South Carolina

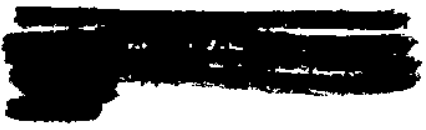

UNCLAS SIFIED 
This report was prepared as an account of Government sponsored work. Ne1ther the United States, nor the Commission, nor any person acting on behalf of the commission:

A. Makes any warranty or representation, expressed or implied, with respect to the accuracy, completeness, on usefulness of the information contained in this report, or that the use of any information, apparatus, method, or process disclosed in this report may not infringe privately owned rights; or

B. Assumes any liabilities with respect to the use of, or for damages resulting from the use of any information, apparatus, method, or process disclosed in this report.

As used in the above, "person acting on behalf of the Commission" includes any employee or contractor of the Commission, or employee of such contractor, to the extent that such employee or contractor of the Commission, or employee of such contractor prepares, disseminates, or provides access to, any information pursuant to his employment or contract with the Commission, or his employment with such contractor.

Printed in USA. Price $\$ 0.35$

Avallable from the U. S. Atomic Energy Commission Technical Information Service Extension

P. 0. Box 1001, Oak Ridge, Tennessee

Please direct to the same address inquiries covering the procurement of other classified AEC reports. 


$$
\text { DP }-768
$$

NUCLEAR TECHNOLOGY - CHEMISTRY

AND CHEMICAL ENGINEERING

$\left(\mathrm{M}-3679,26 \mathrm{th} \mathrm{Ed}_{.}\right)$

This document consists of

$\frac{18}{227}$ Pages, Number 25 of 227 Copies, Series A .

\section{RECOVERY OF NEPTUNIUM FROM STORED PUREX WASTE}

by

Mark D. Snyder

September 1962
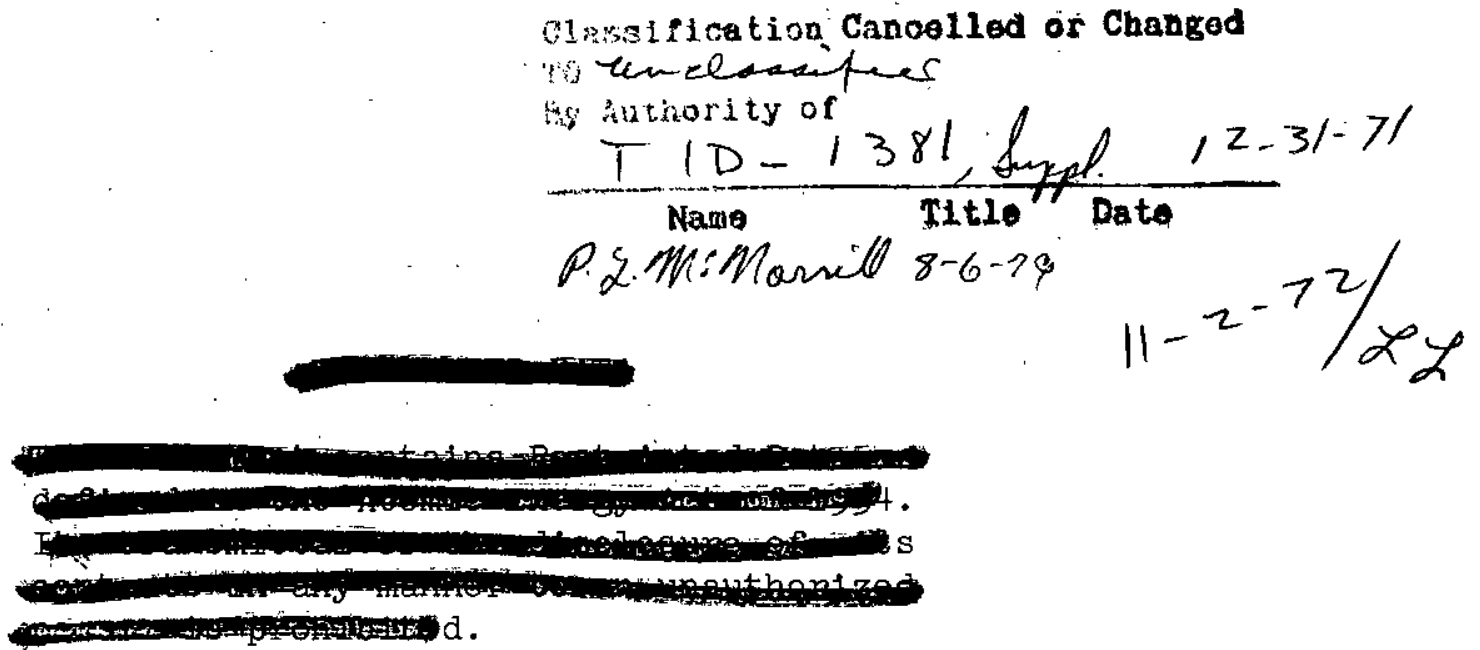

E. I. du Pont de Nemours \& Co.

Explosives Department - Atomic Energy Division

Technical Division - Savannah River Laboratory

Alken, South Carolina

Contract $\operatorname{AT}(07-2)-1$ with the

United States Atomic Energy Commission

Approved by

C. H. Ice, Research Manager

Separations Chemistry D1vision 


\begin{abstract}
A process was developed for the recovery of neptunium from the sludge in stored alkaline wastes from the Purex process at Savannah River. The process involves dissolution of the sludge with $\mathrm{HNO}_{3}$, addition of $\mathrm{KF}$ to the solution and heating to avold gel formation, addition of $\mathrm{Al}\left(\mathrm{NO}_{3}\right)_{3}$ to complex the fluoride, and adjustment to about $8 \mathrm{M}$ total $\mathrm{NO}_{3}{ }^{-}, 0.10 \mathrm{M} \mathrm{N} \mathrm{N}_{2} \mathrm{H}_{4}$, and $0.05 \mathrm{M}$ $\mathrm{Fe}\left(\mathrm{NH}_{2} \mathrm{SO}_{3}\right)_{2}$ for absorption of the neptunium by an agitated bed of anion resin. Laboratory tests with actual sludge showed a recovery of about $90 \%$ of the neptunium and a separation factor from fission products in excess of $10^{3}$. Data on the viscosity of sludge-supernate mixtures and on the settling rate of the sludge particles were obtained for possible use in the design of equipment to remove sludge from the waste tanks.
\end{abstract}


DISTRIBUTION - SERIES A

Copy No.

1-3. AEC, SROO

4-40. Du Pont Company, Atomic Energy D1vision

41. Aerojet-General Corporation

42-43. Aerojet-General Nucleonics

44-49. Aeronautical Systems Division

50. A1r Defense Command

51-52. AlResearch Manufacturing Company, Phoenix

53-54. A1r Force Special Weapons Center

55-56. Albuquerque Operations office

57. Allied Chemical Corporation

58. Allis-Chalmers Manufacturing Company

59. Allis-Chalmers Manufacturing Company, Washington

60. Allison Division-GMC

61-62. Argonne Nat1onal Laboratory

63. Armour Research Foundation

64. Army Chemical Research and Development Laboratories

65-68. Atomic Energy Commission, Washington

69. Atomic Power Development Associates, Inc.

70-71. Atomics International

72. Avco Corporation

73-74. Babcock and Wilcox Company

75. Battelle Memorial Institute

76. Bridgeport Brass Company

77. Bridgeport Brass Company, Ashtabula

78. Brookhaven National Laboratory

79. Bureau of Medicine and Surgery

80. Bureau of Mines, Salt Lake C1ty

81-82. Bureau of Naval Weapons

83. Bureau of Ships

84. Chicago Patent Group

85. Columbia University (NYOO-187)

86. Combustion Engineering, Inc.

87. Combustion Engineering, Inc. (NRD)

88. Continental Army Command

89. Denver Research Institute

90. Director of Defense Research and Englneering (OSD)

91. Division of International Affalrs, Tokyo

92. Dow Chemical Company (Rocky Flats)

93. Edgerton, Germeshausen and Grier, Inc., Goleta

94. Edgerton, Germeshausen and Grier, Inc., Las Vegas

95. Foreign Technical D1vision AFSC

96. Franklin Institute of Pennsylvania

97. General Atomic Division

98. General Dynamics/Astronautics AF

99. Generàl Dỹnamics/Fort "Worth

100-102. General Electric Company, Cinclnnati

103-106. General Electric Company, Richland

107. General Electric Company, San Jose

108. General Electric Company, St. Petersburg

109. General Nuclear Engineering Corporation

110. Gibbs and cox, Inc.

111-112. Goodyear Atomic Corporation

113. Hanford Operations office

114. Iowa State University

115. Jet Propulsion Laboratory

116-117. Knolls Atomic Power Laboratory

118. Lockheed M1ssiles and Space Company 
Copy No.

119-120. Los Alamos Sclentific Laboratory

121. Mallinckrodt Chemical Works

122. Marquardt Corporation

123. Martin-Marietta Corporation

124. Martin-Marletta Corporation, Denver

125. Massachusetts Institute of Technology (Evans)

126. Mound Laboratory

127. NASA Lew1s Research Center

128. NASA Marshall Space Flight Center

129-131. NASA Sclentific and Technical Information Facility

132. National Bureau of Standards

133. National Lead Company of Oh10

134. Naval A1r Material Center

135. Naval Englneering Experiment Station

136. Naval Med1cal Research Institute

137. Naval Postgraduate School

138. Naval Radlolog1cal Defense Laboratory

139. Naval Research Laboratory

140. Naval Weapons Laboratory

141. New Brunswick Area Office

142. New York Naval Sh1pyard

143. New York Operations Office

144. New York Operations office, Canel Division

145. Nuclear Materials and Equipment Corporation

146. Nuclear Metals, Inc.

147. Nuclear Weapons Training Center Atlantic

148. Oak R1dge Operations Office

149. Office of the Assistant General Counsel for Patents (AEC)

150. Offlice of Naval Research

151. Offlce of the Chief of Naval Operations

152-155. Phillips Petroleum Company (NRTS)

156. Pinellas Area Office

157. Pratt and Whitney Alrcraft Division

158. Public Health Service

159. Rand Corporation

160. San Francisco Operations offlce

161. Sandia Corporation

162. Sandia Corporation, L1vermore

163. Surgeon General

164. Tennessee Valley Authority

165. Tracerlab, Inc., Richmond

166-168. Union Carb1de Nuclear Company (ORGDP)

169-173. Union Carbide Nuclear Company (ORNL)

174. Union Carb1de Nuclear Company (Paducan Plant)

175. United Nuclear Corporation (NDA)

176. United Nuclear Corporation (OMC)

177-178. University of Californ1a, Berkeley

179-180. Univers1ty of California, Livermore

181. University of California, Los Angeles

182. University of Washington

183-184. West1nghouse Bettis Atomic Power Laboratory

185. Westinghouse Electric Corporation

186. Westinghouse Electric Corporation (NASA)

187. Yankee Atomlc Electric Company (NYOO-222)

188-227. D1vision of Technical Information Extension 


\section{CONTENTS}

$\underline{\text { Page }}$

Introduction 6

Summary 7

Discussion $\quad 7$

General Properties of the Sludge $\quad 7$

Dissolution of Sludge 10

Stabilization of Sludge Solutions 10

Small-Scale Demonstration of the Process 14

Blbllography 16

\section{LIST OF TABLES AND FIGURES}

$\underline{\text { Table }}$

I Properties of Sludge . . . . 8

II Analysis of Supernate 8

III Recovery of Neptunium from Sludge $\quad 14$

Figure

1 Effect of Concentration on Viscosity of Sludge Suspensions

2 Effect of Fluoride on Recovery of Neptunium from Siudge Solutions

3 Effect of Aluminum/Fluoride Ratio on Recovery of Neptunium from Sludge Solutions 


\section{RECOVERY OF NEPTUNIUM FROM STORED PUREX WASTE}

\section{INTRODUCTION}

In the production of plutonium by neutron irradiation of natural uranium, $\mathrm{Np}^{237}$ is produced by the nuclear reactions

$$
\begin{aligned}
& \mathrm{U}^{238}(\mathrm{n}, 2 \mathrm{n}) \mathrm{U}^{237} \stackrel{\beta^{-}}{\rightarrow} \mathrm{Np}^{237} \\
& \mathrm{U}^{236}(\mathrm{n}, \gamma) \mathrm{U}^{237} \stackrel{\beta^{-}}{\rightarrow} \mathrm{Np}^{237} .
\end{aligned}
$$

Irradiation of $\mathrm{Np}^{237}$ produces $\mathrm{Pu}^{230}$ by the reaction

$$
\mathrm{Np}^{237}(\mathrm{n}, \gamma) \mathrm{Np}^{238} \stackrel{\mathrm{B}^{-}}{\rightarrow} \mathrm{Pu}^{238} .
$$

Because of an increased demand for $\mathrm{Pu}^{238}$, sources of $\mathrm{Np}^{237}$ were consldered to supplement the recovery from the 1rradiated fuels currently being processed. One such source is the stored wastes from the chemical processing of 1rradiated natural uranium.

In the Purex process, the irradiated uranium metal is dissolved in nitric acid, and plutonium and uranium are separated from fission products by extraction with tributyl phosphate. During the extraction of uranium and plutonium, the majority of the neptunium and fission products remalns in the aqueous waste stream. To reduce the volume of waste from chemical processing, the aqueous waste is concentrated by evaporation. This solution is then neutralized with sodium hydroxide and is transferred to tanks for "permanent" storage. The Insoluble hydroxides and manganese dioxide from the head end step of the Purex process settle to the bottom of the waste tanks and form a layer of sludge. Prior to the installation of a process for recovering neptunium from the acidic waste by anion exchange(1), a major fraction of the neptunium from the Purex process accumulated in the sludge in the waste tanks.

This study was undertaken to devise a process for recovering the neptunium from the sludge. Data on the physical nature of the sludge were required to assist in determining whether the siudge in the waste tanks could be suspended and pumped to the chemical processing building. once the sludge was transferred, dissolution of the solids in strong nitric acid and 1solation of the neptunium from solution by anion exchange was considered an attractive concept for the recovery process. Since an anion exchange process (1) for the recovery of neptunium from acidic Purex waste was already being operated successfully at Savannah River Plant, a similar process for the solutions of sludge would be reasonably assured of success. 


\section{SUMMARY}

A concept for a chemical process was developed for the recovery of neptunium from stored Purex waste. The alkaline Purex waste consists of a sludge and a supernatant solution; essentially all of the neptunium in the waste is present in the sludge. In the chemical process that was developed the sludge was dissolved in $10 \mathrm{M} \mathrm{HNO}_{3}$, and neptunium was absorbed from the solution by anion exchange resin. More than $90 \%$ of the neptunium was recovered and was separated from more than $99.9 \%$ of the fission products. Formation of a gelatinous preclpitate in solutions of the dissolved sludge was avolded by adjusting the solution to $0.3 \mathrm{M} \mathrm{KF}$ and then heating at 80 to $90^{\circ} \mathrm{C}$. The resulting solution was adjusted to $0.6 \mathrm{M} \mathrm{Al}\left(\mathrm{NO}_{3}\right)_{3}$ to complex the fluoride, which would otherwise interfere with the absorption of neptunium by anion exchange.

The sludge from the waste tanks was viscous and extremely sticky. However, the sollds in the sludge could be suspended by vigorous agitation with an equal volume of the supernatant solution or water. These suspensions had viscosities of 30 to 70 centipoises and did not settle appreclably over a period of a few days.

\section{DISCUSSION}

\section{GENERAL PROPERTIES OF THE SLUDGE}

The sludge in the tanks of waste from the Purex process forms a layer of partially consolidated, sticky solids. In most tanks, this layer is two to three feet thick and amounts to about 100,000 gallons or about one tenth of the total volume of each tank. In Tanks 12 and 14, which were sampled for this study, about three fourths of the sludge was compacted into a sticky mass, and about one fourth was loosely settled. Samples of the packed sludge were obtained as plugs in a pipe-like sampling device, and samples of the loosely settled sludge were taken in bottles. The general consistency of the packed sludge can be visualized from the observation that massive solids clinging to the outside of the sampling cylinder were not removed in raising the cylinder through about twenty feet of supernate in the waste tanks.

The properties of the sludge and the supernatant solution are shown in Tables I and II. The composition of the solids in the loosely settled layer was not signiflcantly different from the composition of those in the packed layer. When the packed sludge was slurried.with tank supernate or with water, the viscosity of the resulting suspensions decreased as the ratio of liquid to solid volume was increased (Figure 1 ). The viscosity was measured by the flow of the suspensions from transfer plpettes that were callbrated with glycerine solutions of known viscosity in the range of 1.5 to 1000 centipoises. The results of tests with both actual sludge and synthetic sludge indicated-that about 1:1.slurries. of packed sludge and supernate would represent an optimum balance between volume of material to be handled and degree of fluldity necessary for pumping. 
Properties of sludge ${ }^{(a)}$

Tank 12

Viscosity of $50 \%$ slurry, centipoises

Settling rate of $10 \%$ slurry, coarse, in./hr Settling rate of $10 \%$ slurry, fines, in./hr Coarse particles, $\%$

Hydroxides, $\%$

$\mathrm{MnO}_{2}$, \%

Acld insolubles, $\%$

Neutralization equivalent, mols/liter

Neptunium content, mg/11ter

Plutonium content, $\mathrm{mg} / \mathrm{l}$ iter

Neptunium in acid insolubles, $\%$ of total Np

Plutonium in acid insolubles, कo of total Pu

Gross gamma, $d /(\min )(\mathrm{ml})$

Gross beta, $d /(m 1 n)(m 1)$

$\begin{array}{cc}70 & 30 \\ 6 & 2 \\ 1 & 0.1 \\ \sim 95 & \sim 90 \\ \sim 30 & \sim 25 \\ \sim 60 & \sim 60 \\ 10 & 15 \\ 15 & 10 \\ 12-25 & 18-37 \\ \sim 30 & \sim 30 \\ 0.01 & - \\ 3 & - \\ 8.0 \times 10^{9} & 3.2 \times 10^{20} \\ 8.5 \times 10^{10} & 2.4 \times 10^{11}\end{array}$

(a) Samples of sludge were centrifuged for 5 minutes at 1500 G prior to sampling for tests and analyses.

\section{TABIE II}

Analysis of Supernate

\begin{tabular}{|c|c|c|}
\hline Component & Tank 12 & Tank $14^{(a)}$ \\
\hline $\mathrm{OH}^{-}$, as $\mathrm{NaOH}, \mathrm{M}$ & 1.07 & 2.78 \\
\hline $\mathrm{SO}_{4}^{2-}, \mathrm{M}$ & 0.12 & 0.09 \\
\hline $\mathrm{NO}_{3}^{-}, \mathrm{M}$ & 2.27 & 2.62 \\
\hline $\mathrm{NO}_{2}^{-}, \mathrm{M}$ & 2.23 & 0.96 \\
\hline $\mathrm{PO}_{4}{ }^{3-}, \mathrm{M}$ & 0.006 & 0.01 \\
\hline $\mathrm{CO}_{3}^{2-}, \mathrm{M}$ & 0.62 & Not determined $(\mathrm{b})$ \\
\hline $\mathrm{A} 1, \mathrm{M}$ & 0.05 & 0.12 \\
\hline $\mathrm{U}, 8 / 1$ & 0.08 & Not determined \\
\hline Neutralization equivalent, mols/11ter & 3 & Not determined \\
\hline Gross gamma, $a /(\min )(\mathrm{ml})$ & $2.7 \times 10^{9}$ & $4.6 \times 10^{9}$ \\
\hline Gross beta, $d /(\min )(\mathrm{ml})$ & $1.7 \times 10^{\circ}$ & $2.0 \times 10^{9}$ \\
\hline Density, $g / m l$ & 1.25 & Not determined \\
\hline
\end{tabular}




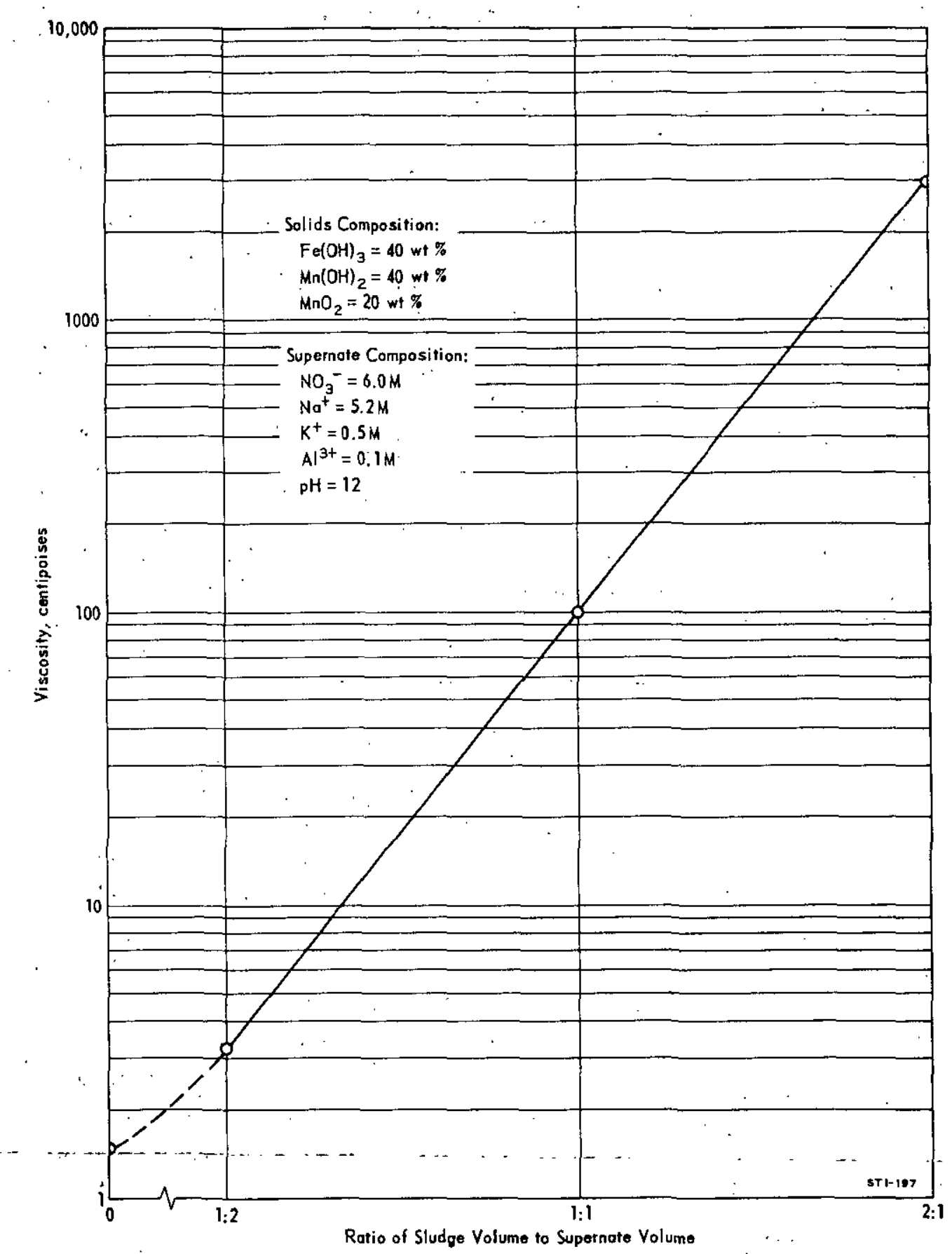

FIG. 1 EFFECT OF CONCENTRATION ON VISCOSITY OF SLUUDGE SUSPENSIONS 
About $90 \%$ of the solids in the sludge were large in size, and settled through the supernate at a rate of about 2 to 6 inches/hr. The remaining $10 \%$ of the solids settled at a slower rate; solids apparently consisted of two groups of particles that were fairly uniform in size. Data on the settling properties of the solids are included in Table I. After standing a few days, the settled layer consisted of about one part of solids and one part of supernate.

\section{DISSOLUTION OF SLUDGE}

About $90 \%$ of the solid matter in the sludge was readily soluble in $10 \mathrm{M}$ $\mathrm{HNO}_{3}$ and the ac1d-insoluble material consisted of easily dispersed solids that contained virtually no neptunium. After dissolution two different precipltates formed from the solution, a brownish floc and a transparent sticky gel. Preclpitation required one to two days at room temperature and ten to sixty minutes at 60 to $90^{\circ} \mathrm{C}$. Normally, the reaction mixture was cooled to avold gelation during the dissolution. Spectroscopic analysis of the precipitates showed silicon, iron, and zirconium to be the major components, and $1 t$ is presumed that the brown floc was mainly iron silicate. The transparent gel probably contained a complex silicate of zirconium. Two sets of tests demonstrated that the metastable compounds were derived from the solids of the sludge. In one set of tests, the precipitates appeared even when the sludge was well rinsed with water and $\mathrm{NaOH}$ solutions to remove supernate before dissolution in $\mathrm{HNO}_{3}$. In the other tests, no more than a trace of precipitate formed when a sample of the supernate was acidified and heated.

Since a major constituent of the sludge was $\mathrm{MnO}_{2}$, it was advantageous to have the supernatant solution present during dissolution. The supernate contalned nitrite from the radiolysis of the alkaline nitrate, which reacted with $\mathrm{MnO}_{2}$ in acid solutions as follows:

$$
\mathrm{MnO}_{2}+\mathrm{HNO}_{2}+\mathrm{HNO}_{3} \rightarrow \mathrm{Mn}\left(\mathrm{NO}_{3}\right)_{2}+\mathrm{H}_{2} \mathrm{O}
$$

Less than half a volume of supernatant solution was required for the complete dissolution of the $\mathrm{MnO}_{2}$ in one volume of sludge; thus any slurry of sludge that was suitable for transfer and handling would contain an adequate volume of supernate for the dissolution. The presence of a large amount of carbonate in the supernates from Tank 12 complicated the dissolution by gassing and severe foaming. Because of a much shorter storage period, supernate from Tank 14 contalned very little carbonate.

\section{STABILIZATION OF SLUDGE SOLUTIONS}

Due to the large volume and the st1cky nature of the gel that is formed in solutions of sludge, these solutions must be stabilized against the formation of gel before the neptunium can be recovered by anion exchange. The composition of the gel was not determined, but its instability in the alkaline waste, initial solubility in acid, and probable polymerization to an insoluble silicate suggested that 1t might contain zirconium or a 
similar agent. It was found that the formation of the gel could be prevented by adding fluoride to the solutions and heating. A small amount of a white floc (probably silica) appeared during heating, but 1ts presence aid not interfere with the operation of the agitated ion exchange bed. No additional precipitate formed when aluminum ion was later added to complex the excess fluoride and prevent interference with the absorption of neptunium by the anion resin.

Fluoride for stabilization was provided by the addition of 2 to $10 \mathrm{M}$ $\mathrm{KF}$ to freshly prepared sludge solutions. It was not feasible to add $\mathrm{KF}$, or $\mathrm{HF}$, to the $1 \mathrm{OM} \mathrm{HNO}_{3}$ used for dissolution of the sludge because the $\mathrm{MnO}_{2}$ in the sludge became coated with an insoluble fluoride of manganese. This insoluble material prevented rapid reaction of $\mathrm{MnO}_{2}$ with the $\mathrm{HNO}_{2}$; a rapld reaction was necessary to dissolve all the $\mathrm{MnO}_{2}$ because the $\mathrm{HNO}_{2}$ was unstable in the presence of acid and was lost from the reaction medium if $\mathrm{MnO}_{2}$ were not readily avallable. Tests of the dissolution with $\mathrm{HNO}_{3}-\mathrm{HF}$, and subsequent treatment of the residual $\mathrm{MnO}_{2}$ with $\mathrm{H}_{2} \mathrm{O}_{2}$, gave rather slow dissolution of the $\mathrm{MnO}_{2}$ and further demonstrated the desirability of dissolving the sludge in $\mathrm{HNO}_{3}$ alone.

The effectiveness of fluoride for preventing gel formation depended on the concentration of fluoride. A concentration of $0.3 \mathrm{M}$ was required to stabilize solutions of sludge from either Tank 12 or Tank 14. ". At $0.2 \mathrm{M}$ fluoride a slight amount of gel was formed, and at $0.1 \mathrm{M}$ fluoride the volume of gel was about half the initial volume of sludge.

Since fluoride is deleterious to the absorption of neptunium by anion exchange, tests were made to determine the degree of interference and to determine the optimum amount of aluminum for complexing the fluoride. The tests depended on determining the distribution of neptunium between. "Dowex" 1-X4, 20-50 mesh anion resin and synthet1c sludge solutions. The distribution values were then interpreted in terms of losses to be expected(1) in the absorption of neptunium by an agitated bed of the resin under similar conditions. The moderate nitrate concentration of $7 \mathrm{M}$ was selected to give high sensitivity to the effects of variables in the test and to indicate a lower practical operating value for the nitrate concentration. The results shown in figures 2 and 3 indicate that losses would be increased about four times with a concentration of only about $0.03 \mathrm{M}$ fluoride, unless aluminum were added to complex the fluoride. The optimum amount of aluminum required was about two mols per mol of fluoride. By comparing these results with extensive results -from-test s-with-other-antons (1), - it. was estimated that the necessary. concentration of $0.3 \mathrm{M}$ fluoride and $0.6 \mathrm{M}$ aluminum in sludge solutions would require a total nitrate concentration of 8.5 to $9.0 \mathrm{M}$ for recovery of at least $90 \%$ of the neptunium. Measurements of the distribution of neptunium between the anion resin and an actual sludge solution $0.2 \mathrm{M}$ in fluoride, $0.4 \mathrm{M}$ in aluminum, and $8.0 \mathrm{M}$ in total nitrate indicated that recovery -of -neptunium on-an'agit ated bed would-be -about $93 \%$. 


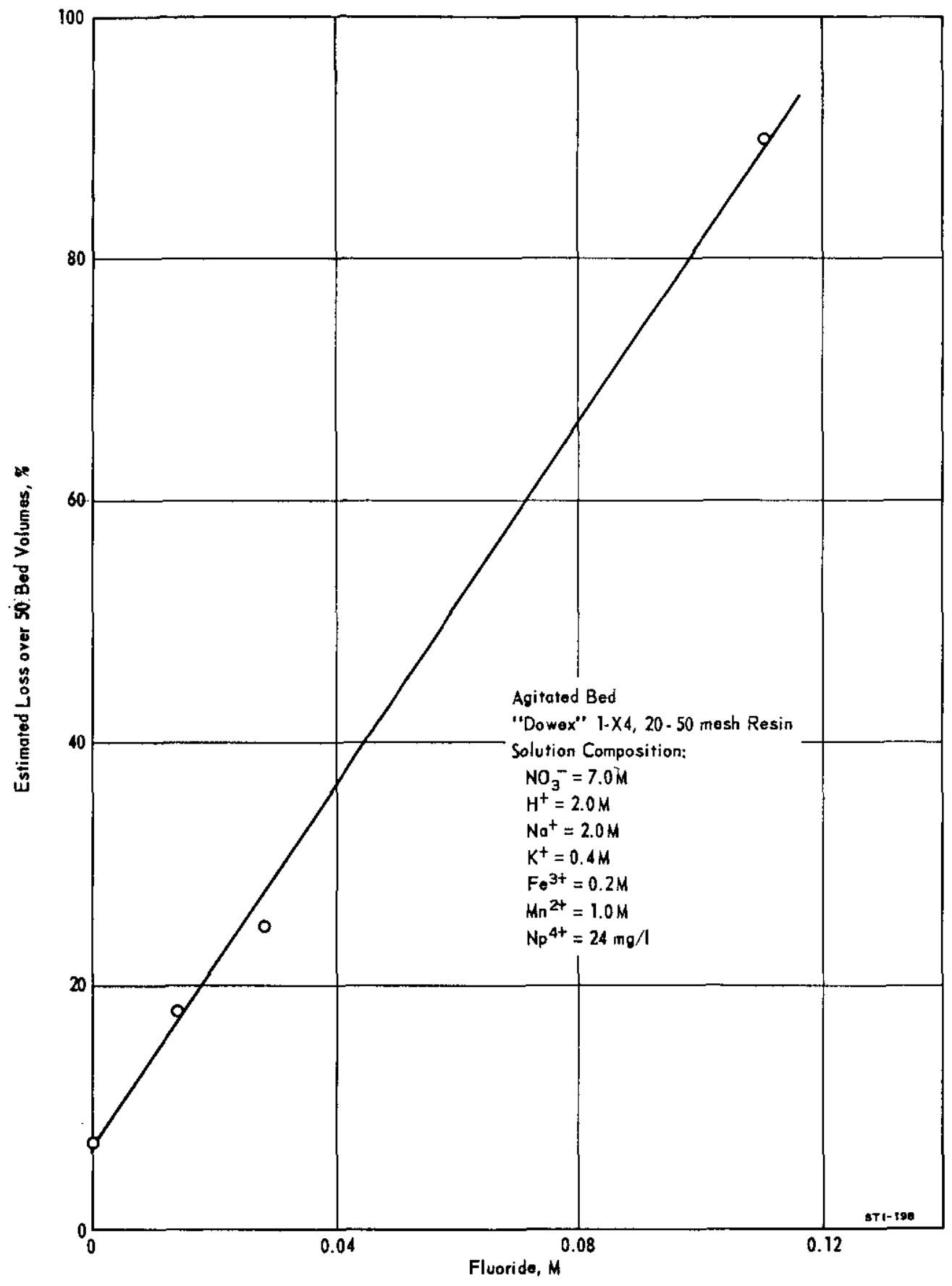

FIG. 2 EFFECT OF FLUORIDE ON RECOVERY OF NEPTUNIUM FROM SLUDGE SOLUTIONS 


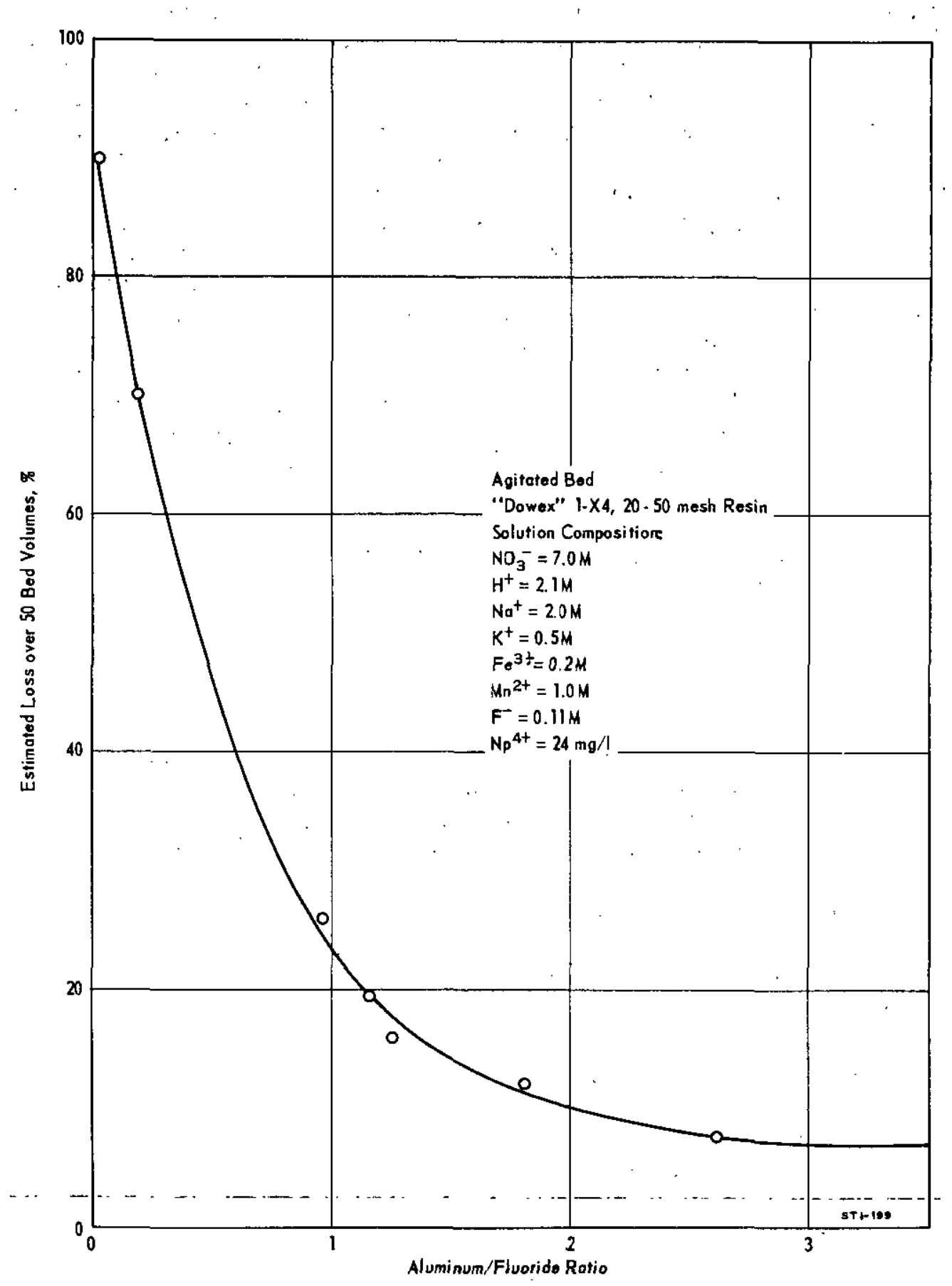

FIG. 3 EFFECT OF ALUMINUM/FLUORIDE RATIIO ON RECOVERY OF NEPTUNIUM FROM SLUDGE SOLUTIONS 


\section{SMALL-SCALE DEMONSTRATION OF THE PROCESS}

Two demonstrations of the process for recovering neptunium from sludge showed neptunium recoveries of 93 to $96 \%$ and decontamination factors from fission products of 600 to 5000 (Table III). The feed prepared from the sludge of Tank 12 consisted partially of sludge dissolved and stabilized in the proposed manner and partially of several sludge solutions prepared under a variety of conditions in the development of the final process. Extra neptunium was added to small portions of the original sample of sludge and subjected to the entire sequence of dissolving and stablizing operations. Analysis of solutions from the different steps indicated that recovery was virtually quantitative until the final isolation by anion exchange. The feed prepared from the sludge of Tank 14 contalned only the neptunium initially present in the sludge. The construction and operation of the agitated bed of anion resin were described previously(i). The $6.5 \mathrm{ml}$ of resin in this apparatus represented a scale-down of about 15,000 from plant equipment.

\section{TABLE III}

Recovery of Neptunium from Sludge

\begin{tabular}{|c|c|c|}
\hline & \multicolumn{2}{|c|}{ Sample } \\
\hline & Tank 12 & Tank 14 \\
\hline Volume of centrifuged sludge, ml & 40 & 70 \\
\hline Volume of supernate, $\mathrm{ml}$ & 20 & 50 \\
\hline Volume of $10 \mathrm{M} \mathrm{HNO}_{3}$, ml & 80 & 115 \\
\hline Volume of centrifuged acid insolubles, ml & 4.0 & 8.6 \\
\hline Concentration of fluoride ion in sludge solution, $M$ & 0.2 & 0.3 \\
\hline Concentration of aluminum ion in sludge solution, M & 0.5 & 0.6 \\
\hline Concentration of nitrate lon in sludge solution, $M$ & $7 \cdot 5$ & 8.8 \\
\hline volume of adjusted feed, ml & 202 & 260 \\
\hline Volume of adfusted feed, bed volumes & 31 & 40 \\
\hline Neptunium in feed solution, mg & $5.00^{(a)}$ & 2.40 \\
\hline Neptunium in absorption effluent, $\not$ & 3.7 & 2.1 \\
\hline Neptunium in $8 \mathrm{M} \mathrm{HNO}_{3}$ wash, $\not$ & 2.5 & 2.1 \\
\hline Neptunium in first eluate ( 4.5 bed volumes), & 90 & 94 \\
\hline Neptunlum in second eluate $(4.5$ bed volumes), $\%$ & 2.9 & 2 \\
\hline Plutonlum in feed, mg & 1.22 & 5.70 \\
\hline Plutonium in absorption effluent, $\phi$ & - & $5 \cdot 3$ \\
\hline Plutonium in first eluate, $\phi$ & 58 & 70 \\
\hline Plutonium in second eluate, $\varnothing$ & 21 & 7 \\
\hline Thorlum in feed, $\mathrm{mg}$ & 0.92 & 0.55 \\
\hline Thorlum in first eluate, $x$ & 7 & 4 \\
\hline Total gross gamma activity in feed, $d / m i n$ & $2.95 \times 10^{11}$ & $2.25 \times 10^{12}$ \\
\hline $\begin{array}{l}\text { Total gross gama activity in first eluate, } \mathrm{d} / \mathrm{min} \\
\text { Decontamination factor }\end{array}$ & $\begin{array}{r}4.4 \times 10^{8} \\
660^{(b)}\end{array}$ & $\begin{array}{l}4.2 \times 10^{0} \\
5400^{(c)}\end{array}$ \\
\hline Total gross gamma activity in second eluate, $d / m i n$ & $1.85 \times 10^{8}$ & $2.45 \times 10^{8}$ \\
\hline
\end{tabular}

(a) Includes $4.00 \mathrm{mg}$ added to sludge

(b) After sixteen bed volumes of wash

(c) After twenty bed volumes of wash 
The baslc steps of the process are as follows:

1. One volume of solid. sludge is slurried with approximately an equal volume of the supernate.

2. The suspension of sludge is treated with an equal volume of $10 \mathrm{M} \mathrm{HNO}_{3}$, with cooling to maintain a temperature of 25 to $40^{\circ} \mathrm{C}$.

3. The solution of sludge, plus about 10\% acid insolubles, is adjusted to $0.3 \mathrm{M} \cdot \mathrm{KF}$ and $1 \mathrm{~s}$ heated for two to four hours at 80 to $90^{\circ} \mathrm{C}$. During this step about one-fourth volume of silica-like precipitate is formed.

4. The solution from step 3 is adjusted to $0.6 \mathrm{M} \mathrm{Al}\left(\mathrm{NO}_{3}\right)_{3}$ and is concentrated to 8 to $9 \mathrm{M}$ total nitrate.

5. The removal of the solids formed in step 3 is recommended; the solids may be removed either before or after step 4.

6. The solution from step 5 is adjusted to $0.10 \mathrm{M} \mathrm{N}_{2} \mathrm{H}_{4}$ and $0.05 \mathrm{M}$ $\mathrm{Fe}\left(\mathrm{NH}_{2} \mathrm{SO}_{3}\right)_{2}$. This treatment reduces neptunium to the absorbable (IV) state.

7. The adjusted solution is passed through an agitated bed of "Dowex" I-X4, 20-50 mesh anion resin at a flow of six bed volumes of solution per hour. During this step, most of the neptunium and associated plutonium is absorbed by the anion resin. The effluent is discarded to waste.

8. The resin is washed, without agitation, with twenty bed volumes of $8 \mathrm{M} \mathrm{HNO}_{3}$ at a rate of $\mathrm{six}$ bed volumes per hour to remove most of the absorbed fission products. In plant operation, only the first two bed volumes of effluent would be discarded to waste.

9. The neptunium, as well as the plutonium, is eluted from the resin with four to flve bed volumes of $0.3 \mathrm{M} \mathrm{HNO}_{3}$ at a rate of two bed volumes per hour. The product solution contains at least $90 \%$ of the neptunium and about $80 \%$ of the plutonium initially present in the sludge. Less than $0.1 \%$ of the fission products are present.

The recovery of neptunium from Purex sludge by this process ylelds five to eight volumes of final neutralized waste per unit volume of solid sludge.

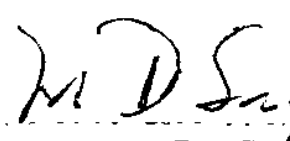

M. D. Snyder Separations Chemistry Division 


\section{BIBLIOGRAPHY}

1. Snyder, M. D. Recovery of Neptunium from Purex Waste by Anion Exchange. E. I. du Pont de Nemours \& Co., Savannah River Laboratory, Aiken, S. C. AEC Research and Development Report DP-742 (Secret) (to be 1ssued). 